\title{
Adipose tissue-derived mesenchymal stem cells and platelet-rich plasma: stem cell transplantation methods that enhance stemness
}

\author{
Morikuni Tobita, Satoshi Tajima and Hiroshi Mizuno*
}

\begin{abstract}
Because of their ease of isolation and relative abundance, adipose-derived mesenchymal stem cells (ASCs) are a particularly attractive autologous cell source for various therapeutic purposes. ASCs retain a high proliferation capacity in vitro and have the ability to undergo extensive differentiation into multiple cell lineages. Moreover, ASCs secrete a wide range of growth factors that can stimulate tissue regeneration. Therefore, the clinical use of ASCs is feasible. However, the potential of ASCs differs depending on the donor's medical condition, including diseases such as diabetes. Recent studies demonstrated that ASCs from diabetic donors exhibit reduced proliferative potential and a smaller proportion of stem cell marker-positive cells. Therefore, to ensure the success of regenerative medicine, tissue engineering methods must be improved by the incorporation of factors that increase the proliferation and differentiation of stem/progenitor cells when autologous cells are used. Platelet-rich plasma (PRP), which contains high levels of diverse growth factors that can stimulate stem cell proliferation and cell differentiation in the context of tissue regeneration, has recently been identified as a biological material that could be applied to tissue regeneration. Thus, co-transplantation of ASCs and PRP represents a promising novel approach for cell therapy in regenerative medicine. In this review, we describe the potential benefits of adding PRP to ASCs and preclinical and clinical studies of this approach in various medical fields. We also discuss the mechanisms of PRP action and future cell-based therapies using co-transplantation of ASCs and PRP.
\end{abstract}

\section{Review}

Mesenchymal stem cells (MSCs) represent independent populations of stem cells with self-renewing properties and an established multipotent differentiation profile in vitro $[1,2]$. Furthermore, they have several advantages in regard to clinical applications for the purpose of repairing or regenerating damaged tissues, especially because they avoid the ethical issues raised by the use of embryonic stem cells [3].

Numerous clinical studies using MSCs have been performed in various fields. Autologous MSCs represent an attractive source for cell-based regenerative medicine because these immature cells are present in the bone marrow, peripheral blood, menstrual blood, and nearly

\footnotetext{
* Correspondence: hmizuno@juntendo.ac.jp

Department of Plastic and Reconstructive Surgery, Juntendo University School of Medicine, 2-1-1 Hongo, Bunkyo, Tokyo 1138421, Japan
}

all adult tissues (for example, adipose tissue, synovium, dermis, periosteum, and deciduous teeth), as well as in solid organs (for example, liver, spleen, and lung) [4-6]. In particular, adipose-derived stem cells (ASCs) obtained from lipoaspirates have multilineage potential; that is, they are capable of differentiating into adipogenic, chondrogenic, myogenic, osteogenic, and neurogenic cells $[7,8]$. Thus, ASCs could be used in clinical applications for the repair of damaged tissues, as well as for angiogenic therapy. Injection of human ASCs was recently shown to induce osteoid matrix formation and improve neovascularization in an ischemic hind limb in immunotolerant mice [9-11]. Similarly, ASCs can increase the functional capacity of damaged skeletal muscle in vivo [12]. Moreover, ASCs are abundant and easy to harvest from patients' inguinal fat pads. 
However, although cell-based therapies using ASCs are a promising approach for regenerating damaged tissues, the detailed mechanisms underlying the regenerative pathways of transplanted ASCs are not clearly understood. Recent publications have suggested that ASC differentiation may not be the main regenerative mechanism in cell therapy, although the multipotent characteristics of these preparations have been demonstrated in vitro and have attracted the greatest attention from the standpoint of their use in tissue engineering approaches. Most of the beneficial effects of stem cells might be attributed to soluble factors released from stem cells [3]. However, several groups report that ASCs derived from different tissues not only share many similarities but also seem to exhibit differences in terms of marker expression and biological properties [3]. Furthermore, the biological properties of ASCs are influenced by systemic disease such as diabetes. ASCs isolated from type 2 diabetics exhibit elevated levels of cellular senescence and apoptosis, as well as altered differentiation capacity [13]. Similarly, Cianfarani et al. [14] reported that stromal vascular fractions (SVFs) isolated from diabetic animals exhibit several alterations. In material obtained from diabetic donors, the percentage of cells expressing stem cell-specific membrane markers in SVFs and cultured cells is reduced. Moreover, the levels of vascular endothelial growth factor (VEGF)-A, hepatocyte growth factor (HGF), and insulin-like growth factor (IGF)-1 in the conditioned medium of diabetic ASCs are also reduced. These observations suggest that diabetic ASCs suffer from impairments in the ability to produce or release factors that mediate cell signaling [15].

Recently, platelet-rich plasma (PRP) was introduced in tissue engineering as a source of large quantities of growth factors, and this material has been applied as a novel matrix to enhance the properties of transplanted cells. PRP has been used clinically in humans since the 1970s for its wound-healing properties, which are attributed to its high levels of growth factors and secretory proteins [16]. The growth factors in PRP promote the recruitment, proliferation, and differentiation of cells involved in tissue regeneration [17].

Preclinical studies using ASCs and PRP in combination have been conducted in the contexts of periodontal tissue engineering [18, 19], wound healing [20], tendon repair [21], and bone regeneration [22]. These reports demonstrate the potential of PRP as a cell carrier (scaffold) to increase the potential of the transplanted cells used in stem cell therapies. Therefore, it is possible that PRP could contribute to stem cell therapies.

The purpose of this article is to describe the basic science of ASCs and PRP, the potential benefits of adding PRP to ASCs, and preclinical and clinical studies in various medical fields. We also discuss the mechanisms of
PRP action and future cell-based therapies using cotransplantation of ASCs and PRP.

\section{Characterization of adipose-derived stem cells}

Adipose tissue contains SVFs including pre-adipocytes, fibroblasts, vascular smooth muscle cells, endothelial cells, resident monocytes/macrophages, lymphocytes and ASCs, and is composed mainly of fat cells organized into lobules [23, 24].

Stem cell yields from adipose tissue are greater than those from other stem cell reservoirs, making them especially suitable for use in regenerative medicine. Routinely, $10^{7}$ adipose stromal/stem cells can be isolated from $300 \mathrm{ml}$ of lipoaspirate with greater than $95 \%$ purity $[23,25]$. ASCs comprise approximately $2 \%$ of the nucleated cells in processed lipoaspirate, and the yield of ASCs is approximately 5000 fibroblast colonyforming units (CFU-F) per gram of adipose tissue, compared with approximately 100 to $1000 \mathrm{CFU}-\mathrm{F}$ per ml of bone marrow [26].

In 2006, the International Society for Cellular Therapy proposed minimal phenotypic criteria for the definition of cultured MSCs. The main criteria for MSCs are: (1) adhesion to plastic; (2) more than $95 \%$ of the MSC population must express CD73, CD90, and CD105 and their population must lack expression of CD34, CD45, CD11b or CD14, CD79 or CD19, and HLA class II (less than $2 \%$ should express these); and (3) tri-lineage differentiation potential $[27,28]$. In its position statement, the Society also specified CD34 as a negative marker for MSCs [27], but recent reports show that this marker must be evaluated in the context of the tissue from which the MSCs were isolated.

Reports of the percentage of SVF cells expressing CD34 vary greatly [29-32]. Up to $85 \%$ of the cells in SVFs express CD34 [30, 33, 34]. Two days after plastic adherence, more than $95 \%$ of cells express CD34, coexpress mesenchymal (CD10/CD13/CD90) and pericytic markers (CD140a and -b), and are CD31-/CD45- [35]. Furthermore, distinct CD34+ subpopulations have been described [30, 31, 36].

\section{Factors that decrease stemness in adipose-derived stem cells}

ASCs can be expanded ex vivo in a relatively short period of time [37-39]; however, their 'stemness', defined by their potential to proliferate and differentiate, gradually decreases during serial passage [37].

The differentiation capacity of ASCs may not be involved in their primary regenerative mechanism in cell therapy; however, the multipotent character of these preparations has been demonstrated in vitro and is the main focus of attention in the context of their use in tissue engineering [3]. ASCs secrete cytokines, growth 
factors, and bioactive molecules with trophic paracrine effects in response to local microenvironmental cues, and these factors are likely to mediate the main mechanisms underlying the regenerative and repair potential of these cells [40]. However, a large number of studies show that cultured ASC preparations are heterogeneous and consist of different populations of stem and progenitor cells with self-renewal properties and multipotent differentiation profiles [2]. The heterogeneity of ASC preparations may be due to various causes, including inter-donor differences in age, body mass index, gender, ethnicity, and disease status [1]. Sethe et al. [41] reported that MSCs from older donors show no spindleshaped morphology in culture compared with MSCs from younger donors. In another report, $\mathrm{Xu}$ et al. [42] demonstrated that the osteogenic differentiation potential of ASCs is related to donor age. Body mass index correlates negatively with the number of stromal cells per gram and their differentiation capacity [1]. In addition, Gimble et al. [43] suggested that brown adipose tissue and white adipose tissue show different capacities with regard to cell proliferation and yield of stem cells. Furthermore, epigenetic changes affect stem cell growth and cell differentiation potential. Yan et al. [44] reported that pretreatment with 5-azacytidine improved proliferation and osteogenic differentiation of ASCs from older donors.

In particular, systemic diseases such as diabetes influence the properties of ASCs. Because the hyperglycemic diabetic environment may impact aspects of stemness, including the phenotype, morphology, and differentiation potential of ASCs, the potential use of autologous cell therapies in diabetic patients has caused controversy. Several studies demonstrate that the ASCs from diabetics have impaired function relative to ASCs from non-diabetic donors [15]. In ASCs from diabetic rats, for example, MSC markers are downregulated, and viability and differentiation potential are reduced $[45,46]$. Based on the reduced proliferative potential and migration and limited therapeutic potential of autologous ASCs when administered to wounds of diabetic mice, some authors have questioned the efficiency of autologous therapies in diabetic patients [14, 47]. In an in vivo study, ASCs from streptozotocin-induced type 1 diabetic mice exhibited reduced proliferative potential and migration, and diabetic ASCs released lower amounts of HGF, VEGF-A, and IGF-1 [14]. Although autologous ASC administration improves healing in diabetic skin repair [48], functional impairment in resident and recruited cells strongly contributes to delayed wound healing in diabetic subjects [49-54]. Therefore, it is essential to evaluate the impact of the diabetic milieu on clinical applications of ASCs. In a clinical trial in which autologous ASCs were used for the treatment of critical limb ischemia, ASCs from diabetic patients had fibrinolytic activity, which was suggested to cause peripheral microthrombosis [55].

\section{Factors that increase stemness in adipose-derived stem} cells, and the potential of platelet-rich plasma

Recent reports suggested that certain growth factors, such as vascular VEGF, fibroblast growth factor (FGF)-2, FGF-4, FGF-6, FGF-7, FGF-9, FGF-17, transforming growth factor (TGF)-beta1, TGF-beta2, HGF, keratinocyte growth factor, platelet-derived growth factor AA, and IGF-1, regulate the maintenance of ASC stemness [37]. These factors affect a plethora of responses such as angiogenesis, cellular migration, apoptosis, proliferation, and differentiation [56-59]. In particular, the proliferation of ASCs is regulated by paracrine factors such as FGF-2, FGF-4, interleukin (IL)-6, and stromal-derived factor 1, whereas FGF-2, endothelial growth factor, TGFbeta, and other factors are involved in differentiation $[60,61]$.

Platelets contain critical growth factors and mediators of tissue repair pathways. Activation of platelets with calcium chloride induces immediate platelet growth factor release in vitro [62]. PRP obtained from autologous blood contains a high concentration of stored autologous growth factors. Exposure of PRP to calcium chloride induces platelet degranulation. Several studies describe the potential benefits of using PRP in tissue regeneration; in particular, PRP therapy has been proposed in wound healing. Moreover, because PRP is able to stimulate proliferation of undifferentiated stem cells as well as cell differentiation, it might be used in conjunction with stem cell transplantation to promote tissue regeneration [63-66].

However, although the biological mechanism and clinical effect of PRP remain poorly understood, some studies on the mechanism of action of PRP have been reported recently. Andia et al. [67] demonstrated that human PRP induces an immunomodulatory and proangiogenic phenotype consistent with healing mechanisms of inflamed tenocytes in vitro. The expression of some crucial inflammatory molecules, including IL-6 and IL-8, was downregulated in response to PRP treatment.

Furthermore, various methods for manipulating PRP have been reported. For example, the platelet concentration in plasma [68], the volume of PRP transplantation, and the method of activation contribute to the effect of PRP on cell proliferation and differentiation directly. For these reasons, appropriate methods when using PRP are still controversial.

On the other hand, the fibrin network of PRP has the potential to serve as a scaffold. We have shown that this network can hold cells and platelets in a threedimensional arrangement within the PRP (Fig. 1). This cell-PRP interaction may increase stemness and prolong the survival time and rate of cells in the PRP. 

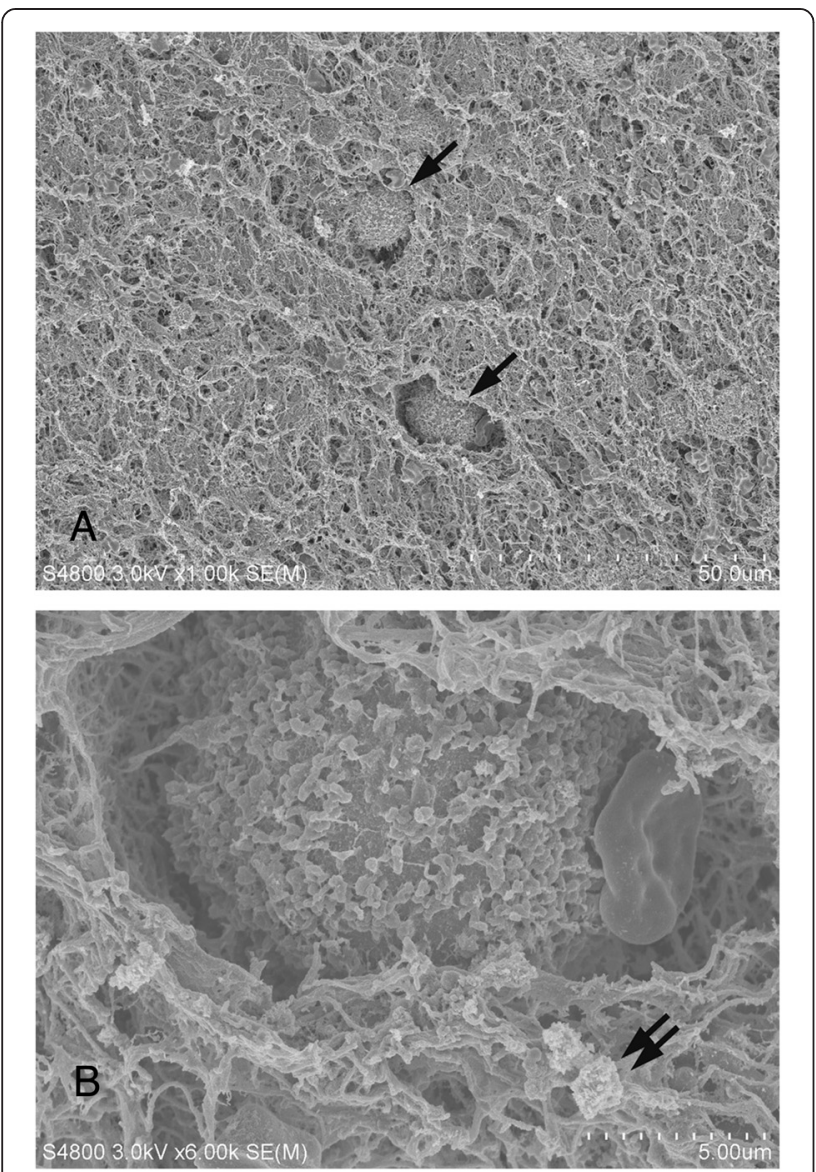

Fig. 1 a Low-magnification scanning electron microscopy (SEM) image of a mixture of adipose-derived stem cells (ASCs) with activated plateletrich plasma (PRP). Some ASCs are arranged three-dimensionally in the fibrin network of the activated PRP. $\mathbf{b}$ High-magnification SEM image of panel $\mathbf{a}$. Some platelets reside around the ASCs. Arrows indicate ASCs and double arrows indicate platelets

Therefore, the co-transplantation of ASCs and PRP represents an attractive approach for autologous cell therapies.

\section{Preclinical and clinical studies using adipose-derived stem cells and platelet-rich plasma}

Recently, research comparing ASCs alone or in combination with PRP have been reported. Kim et al. [69] compared fat graft survival with PRP, ASCs, and SVFs in a mouse model. Transplanted fat tissue with ASCs or SVFs was effective in preventing volume reduction of fat tissue compared with conventional fat graft or adding PRP. In another study, human ASCs or adipocytes were cultured with PRP in vitro [70]. The results showed that ASC viability was strongly increased in the presence of $5 \%$ or 20 \% PRP. Furthermore, levels of IL-6, IL-8, IL-10, VEGF and interferon- $\gamma$ were significantly increased in PRPtreated adipocytes [70]. Atashi et al. [71] reported that
20 \% PRP was the most effective concentration to promote ASC proliferation. Recently, Xu et al. [42] reported that activated PRP promoted proliferation and differentiation of human ASCs in vitro. Interestingly, the effects of PRP on ASC proliferation and osteogenic differentiation were dose-dependent.

Recently, co-transplantation of ASCs and PRP has been extensively investigated, and the role of PRP factors as powerful paracrine effectors in ASC transplantation has been demonstrated in preclinical and clinical studies (Table 1).

Numerous preclinical studies have demonstrated the efficacy of co-transplantation of ASCs and PRP in a wide range of model systems. Van Pham et al. [72] transplanted ASCs cultured with $15 \%$ PRP into the articular cartilage injury model of NOD/SCID mice. Their results showed that PRP-pretreated ASCs improved healing of injured articular cartilage more effectively than untreated ASCs. In a bone regeneration study, Tajima et al. [22] transplanted rat ASCs and PRP into a rat calvarial defect model. They found that co-transplantation of ASCs and PRP significantly improved bone regeneration; furthermore, 8 weeks after transplantation, the volume of regenerated bone was significantly greater when PRP and ASCs were transplanted together than when PRP or ASCs in collagen gel were used alone. In another study, Tobita et al. [18] transplanted a combination of rat ASCs and PRP into a periodontal tissue defect in Wistar rats. Eight weeks after this treatment, histological observation revealed regeneration of alveolar bone, periodontal ligament-like structures, and cementum-like structures in the periodontal tissue defect. Likewise, when canine-derived ASCs were transplanted with PRP, regeneration of these periodontal tissues was greatly improved relative to PRP-treated or saline-treated control subjects 8 weeks after transplantation [19]. Tobita and Mizuno [24] transplanted uncultured human SVFs, taken from subcutaneous fat tissue, along with PRP into a periodontal tissue defect in nude rats; this treatment resulted in extensive improvement of periodontal tissue 8 weeks after transplantation. A recent study reported the transplantation of a combination of ASCs and PRP for treatment of bisphosphonaterelated osteonecrosis of the jaw in a rat model [73]. The results demonstrated that a lower frequency of osteonecrosis was associated with the combination of ASCs and PRP.

Likewise, in clinical studies, combined transplantation of ASCs and PRP has shown great promise. Koh et al. [74] injected a combination of ASCs and PRP into 18 patients with osteoarthritis or degenerative cartilage, and found that this treatment effectively reduced pain and improved knee function in patients being treated for knee osteoarthritis. Pak et al. [75] investigated the 
Table 1 Preclinical and clinical studies using adipose-derived stem cells and platelet-rich plasma

\begin{tabular}{|c|c|c|c|c|c|}
\hline $\begin{array}{l}\text { Type of cells } \\
\text { (SVFs or ASCs) } \\
\end{array}$ & Species of cells & $\begin{array}{l}\text { How to use } \\
\text { the PRP }\end{array}$ & Animal model/disease & Results & Reference \\
\hline \multicolumn{6}{|c|}{ Preclinical studies } \\
\hline ASCs & Human & Co-administration & $\begin{array}{l}\text { Mouse full thickness } \\
\text { wound model }\end{array}$ & $\begin{array}{l}\text { Co-administration of PRP and ASCs } \\
\text { in the wound beds increased ASC } \\
\text { survival and enhanced arteriole } \\
\text { formation in wounds }\end{array}$ & {$[20]$} \\
\hline ASCs & Rat (Wistar) & Co-administration & $\begin{array}{l}\text { Osteonecrosis of } \\
\text { the jaw }\end{array}$ & $\begin{array}{l}\text { The combination of ASCs and PRP } \\
\text { prevented frequency of bisphosphonate- } \\
\text { related osteonecrosis of the jaw }\end{array}$ & [73] \\
\hline ASCs & Rabbit & Co-transplantation & $\begin{array}{l}\text { Achilles tendon } \\
\text { injured model }\end{array}$ & ASCs differentiated into tenocytes & {$[21]$} \\
\hline ASCs & Human & $\begin{array}{l}\text { ASCs were treated } \\
\text { with } 15 \% \text { PRP in } \\
\text { culture flask }\end{array}$ & $\begin{array}{l}\text { Mouse model of } \\
\text { articular cartilage injury }\end{array}$ & $\begin{array}{l}\text { PRP-treated ASCs improved healing } \\
\text { of injured articular cartilage }\end{array}$ & [72] \\
\hline ASCs & Rat (Fischer) & Co-transplantation & Rat calvarial defect & $\begin{array}{l}\text { Regenerated volume of bone was } \\
\text { significantly greater than in the } \\
\text { PRP-treated group and ASCs/ } \\
\text { collagen gel-treated group } 8 \text { weeks } \\
\text { after transplantation }\end{array}$ & [22] \\
\hline ASCs & Rat (Wistar) & Co-transplantation & $\begin{array}{l}\text { Rat periodontal } \\
\text { tissue defect }\end{array}$ & $\begin{array}{l}\text { Alveolar bone, periodontal ligament- } \\
\text { like structures, and cementum-like } \\
\text { structures were observed in the } \\
\text { periodontal tissue defect } 8 \text { weeks } \\
\text { after transplantation }\end{array}$ & {$[18]$} \\
\hline ASCs & Canine & Co-transplantation & $\begin{array}{l}\text { Canine periodontal } \\
\text { tissue defect }\end{array}$ & $\begin{array}{l}\text { Periodontal tissue regeneration was } \\
\text { observed in the bifurcation defect } \\
8 \text { weeks after transplantation }\end{array}$ & [19] \\
\hline SVFs & Human & Co-transplantation & $\begin{array}{l}\text { Rat periodontal } \\
\text { tissue defect }\end{array}$ & $\begin{array}{l}\text { Human SVFs have the potential to } \\
\text { regenerate periodontal tissue }\end{array}$ & [24] \\
\hline \multicolumn{6}{|l|}{ Clinical studies } \\
\hline ASCs & Human & Co-transplantation & Osteoarthritis & $\begin{array}{l}18 \text { patients were treated. Intra-articular } \\
\text { injection of a combination of ASCs and } \\
\text { PRP effectively reduced pain and improved } \\
\text { knee function in patients being treated for } \\
\text { knee osteoarthritis }\end{array}$ & [74] \\
\hline SVFs & Human & Co-transplantation & Articular joints & $\begin{array}{l}91 \text { patients were treated with autologous } \\
\text { SVFs with PRP over } 2 \text { years }\end{array}$ & {$[75]$} \\
\hline
\end{tabular}

ASC adipose-derived stem cell; PRP platelet-rich plasma; SVF stromal vascular fraction

safety of implanting autologous SVFs and PRP into articular joints; in this study, 91 patients were treated with a combination of autologous SVFs with PRP over the course of 2 years.

\section{Conclusion}

ASCs hold great potential for use in stem cell therapy. After being transplanted, however, ASCs face a complex and hostile environment in which local hypoxia, oxidative stress, and inflammation may lead to cell loss or death on a large scale. Furthermore, the stemness properties of ASCs are influenced by the disease state of the donor. Insufficient retention and survival of transplanted ASCs can dramatically reduce their therapeutic effects [76]. Therefore, tissue engineering approaches need to be dramatically improved by the addition of adjuncts that increase the proliferation and differentiation of
ASCs. In this regard, PRP is an attractive cell-maintained biomaterial, and the activated PRP scaffold can enhance the stemness properties of ASCs, although further analysis and investigation are needed to establish novel cell therapies.

In particular, risk assessments of cell transplantation in clinical studies are especially important because clinical efficacy and safety depend on the manipulation of various factors, culture conditions, and quality risk management.

The evidence compiled to date suggests that this combination treatment represents a promising approach in various fields of medicine and dentistry.

Note: This article is part of a thematic series 'Mesenchymal Stem/Stromal Cells_-An update'. Other articles in this series can be found at http://www.biomedcentral.com/series/mesenchymal 


\section{Abbreviations}

ASC: Adipose-derived stem cell; CFU-F: Fibroblast colony-forming units; FGF: Fibroblast growth factor; HGF: Hepatocyte growth factor; IGF: Insulinlike growth factor; IL: Interleukin; MSC: Mesenchymal stem cell; PRP: Platelet-rich plasma; SVF: Stromal vascular fraction; TGF: Transforming growth factor; VEGF: Vascular endothelial growth factor.

\section{Competing interests}

The authors declare that they have no competing interests.

\section{Authors' contributions}

All authors contributed to the writing of the manuscript, and read and approved the final version.

\section{Published online: 05 November 2015}

\section{References}

1. Baer PC, Geiger H. Adipose-derived mesenchymal stromal/stem cells: tissue localization, characterization, and heterogeneity. Stem Cells Int. 2012;2012:812693

2. Dominici M, Paolucci $P$, Conte $P$, Horwitz EM. Heterogeneity of multipoten mesenchymal stromal cells: from stromal cells to stem cells and vice versa. Transplantation. 2009;87(9 Suppl):S36-42.

3. Baer PC. Adipose-derived mesenchymal stromal/stem cells: an update on their phenotype in vivo and in vitro. World J Stem Cells. 2014;6:256-65.

4. Da Silva ML, Chagastelles PC, Nardi NB. Mesenchymal stem cells reside in virtually all post-natal organs and tissues. J Cell Sci. 2006;119:2204-13.

5. Kassis I, Zangi L, Rivkin R, Levdansky L, Samuel S, Marx G, et al. Isolation of mesenchymal stem cells from G-CSF-mobilized human peripheral blood using fibrin microbeads. Bone Marrow Transplant. 2006;37:967-76.

6. Zou Z, Zhang Y, Hao L, Wang F, Liu D, Su Y, et al. More insight into mesenchymal stem cells and their effects inside the body. Expert Opin Biol Ther. 2010;10:215-30.

7. Zuk PA, Zhu M, Mizuno H, Huang J, Futrell JW, Katz AJ, et al. Multilineage cells from human adipose tissue: implications for cell-based therapies. Tissue Eng. 2001:7:211-28.

8. Mizuno H, Zuk PA, Zhu M, Lorenz HP, Benhaim P, Hedrick MH. Myogenic differentiation by human processed lipoaspirate cells. Plast Reconstr Surg. 2002;109:199-209. discussion 210-11.

9. Puissant B, Barreau C, Bourin P, Clavel C, Corre J, Bousquet C, et al. Immunomodulatory effect of human adipose tissue-derived adult stem cells: Comparison with bone marrow mesenchymal stem cells. $\mathrm{Br} J$ Haematol. 2005:129:118-29.

10. Hicok KC, Du Laney TV, Zhou YS, Halvorsen Y-DC, Hitt DC, Cooper LF, et al Human adipose-derived adult stem cells produce osteoid in vivo. Tissue Eng. 2004;10:371-80.

11. Miranville A, Heeschen C, Sengenès C, Curat CA, Busse R, Bouloumié A. Improvement of postnatal neovascularization by human adipose tissuederived stem cells. Circulation. 2004;110:349-55.

12. Bacou F, Boubaker El Andalousi R, Daussin PA, Micallef JP, Levin JM, Chammas M, et al. Transplantation of adipose tissue-derived stromal cells increases mass and functional capacity of damaged skeletal muscle. Cell Transplant. 2004;13:103-11.

13. Cramer C, Freisinger E, Jones RK, Slakey DP, Dupin CL, Newsome ER, et al. Persistent high glucose concentrations alter the regenerative potential of mesenchymal stem cells. Stem Cells Dev. 2010;19:1875-84.

14. Cianfarani F, Toietta G, Di Rocco G, Cesareo E, Zambruno G, Odorisio T. Diabetes impairs adipose tissue-derived stem cell function and efficiency in promoting wound healing. Wound Repair Regen. 2013;21:545-53.

15. Ko Z, Turnovcová K, Dubský M, Baranovi L, Holá V, Chudí M, et al. Characterization of human adipose tissue-derived stromal cells isolated from diabetic patient's distal limbs with critical ischemia. Cell Biochem Funct. 2014:32:597-604.

16. Mei-Dan O, Laver L, Nyska M, Mann G. Platelet rich plasma—a new biotechnology for treatment of sports injuries. Harefuah. 2011;150:453-7. 490,

17. Nurden AT. Platelets, inflammation and tissue regeneration. Thromb Haemost. 2011:105 Suppl 1:13-33.

18. Tobita M, Uysal AC, Ogawa R, Hyakusoku H, Mizuno H. Periodontal tissue regeneration with adipose-derived stem cells. Tissue Eng $A$. 2008; 14:945-53.
19. Tobita M, Uysal CA, Guo X, Hyakusoku H, Mizuno H. Periodontal tissue regeneration by combined implantation of adipose tissue-derived stem cells and platelet-rich plasma in a canine model. Cytotherapy. 2013:15:1517-26.

20. Bhang SH, Park J, Yang HS, Shin J, Kim BS. Platelet-rich plasma enhances the dermal regeneration efficacy of human adipose-derived stromal cells administered to skin wounds. Cell Transplant. 2013;22:437-45.

21. Uysal CA, Tobita M, Hyakusoku H, Mizuno H. Adipose-derived stem cells enhance primary tendon repair: biomechanical and immunohistochemical evaluation. J Plast Reconstr Aesthet Surg. 2012;65:1712-9.

22. Tajima S, Tobita M, Orbay H, Hyakusoku H, Mizuno H. Direct and indirect effects of a combination of adipose-derived stem cells and platelet-rich plasma on bone regeneration. Tissue Eng A. 2015;21:895-905.

23. Mizuno $H$, Tobita M, Uysal AC. Adipose-derived stem cells as a novel tool for future regenerative medicine. Stem Cells. 2012;30:804-10.

24. Tobita M, Mizuno H. Adipose-derived stem cells and platelet-rich plasma: the keys to functional periodontal tissue engineering. Curr Stem Cell Res Ther. 2013;8:400-6.

25. Boquest AC, Shahdadfar A, Brinchmann JE, Collas P. Isolation of stromal stem cells from human adipose tissue. Methods Mol Biol. 2006;325:35-46.

26. Strem BM, Hicok KC, Zhu M, Wulur I, Alfonso Z, Schreiber RE, et al, Multipotential differentiation of adipose tissue-derived stem cells. Keio Med. 2005:54:132-41.

27. Dominici M, Le Blanc K, Mueller I, Slaper-Cortenbach I, Marini F, Krause D et al. Minimal criteria for defining multipotent mesenchymal stromal cells. The International Society for Cellular Therapy position statement. Cytotherapy. 2006;8:315-7.

28. Horwitz EM, Le Blanc K, Dominici M, Mueller I, Slaper-Cortenbach I, Marini FC, et al. Clarification of the nomenclature for MSC: The International Society for Cellular Therapy position statement. Cytotherapy. 2005;7:393-5.

29. Zimmerlin L, Donnenberg VS, Pfeifer ME, Meyer EM, Péault B, Rubin JP, et al. Stromal vascular progenitors in adult human adipose tissue. Cytom $A$. 2010;77:22-30

30. Varma MJO, Breuls RGM, Schouten TE, Jurgens WJFM, Bontkes HJ, Schuurhuis GJ, et al. Phenotypical and functional characterization of freshly isolated adipose tissue-derived stem cells. Stem Cells Dev. 2007:16:91-104.

31. Astori G, Vignati F, Bardelli S, Tubio M, Gola M, Albertini V, et al. "In vitro" and multicolor phenotypic characterization of cell subpopulations identified in fresh human adipose tissue stromal vascular fraction and in the derived mesenchymal stem cells. J Transl Med. 2007;5:55.

32. Quirici N, Scavullo C, de Girolamo L, Lopa S, Arrigoni E, Deliliers GL, et al. Anti-L-NGFR and -CD34 monoclonal antibodies identify multipotent mesenchymal stem cells in human adipose tissue. Stem Cells Dev. 2010;19:915-25.

33. Scherberich A, Di Maggio N, McNagny KM. A familiar stranger: CD34 expression and putative functions in SVF cells of adipose tissue. World J Stem Cells. 2013;5:1-8.

34. Planat-Benard V, Silvestre J-S, Cousin B, André M, Nibbelink M, Tamarat R et al. Plasticity of human adipose lineage cells toward endothelial cells: physiological and therapeutic perspectives. Circulation. 2004;109:656-63.

35. Traktuev DO, Merfeld-Clauss S, Li J, Kolonin M, Arap W, Pasqualini R, et al. A population of multipotent CD34-positive adipose stromal cells share pericyte and mesenchymal surface markers, reside in a periendothelial location, and stabilize endothelial networks. Circ Res. 2008;102:77-85.

36. Oedayrajsingh-Varma MJ, van Ham SM, Knippenberg M, Helder MN, KleinNulend J, Schouten TE, et al. Adipose tissue-derived mesenchymal stem cell yield and growth characteristics are affected by the tissue-harvesting procedure. Cytotherapy. 2006;8:166-77.

37. Eom YW, Oh J-E, Lee Jl, Baik SK, Rhee K-J, Shin HC, et al. The role of growth factors in maintenance of stemness in bone marrow-derived mesenchymal stem cells. Biochem Biophys Res Commun. 2014:445:16-22.

38. Colter DC, Class R, DiGirolamo CM, Prockop DJ. Rapid expansion of recycling stem cells in cultures of plastic-adherent cells from human bone marrow. Proc Natl Acad Sci U S A. 2000;97:3213-8.

39. Sekiya I, Larson BL, Smith JR, Pochampally R, Cui J-G, Prockop DJ. Expansion of human adult stem cells from bone marrow stroma: conditions that maximize the yields of early progenitors and evaluate their quality. Stem Cells. 2002:20:530-41. 
40. Murphy MB, Moncivais K, Caplan Al. Mesenchymal stem cells: environmentally responsive therapeutics for regenerative medicine. Exp Mol Med. 2013;45:e54.

41. Sethe S, Scutt A, Stolzing A. Aging of mesenchymal stem cells. Ageing Res Rev. 2006;5:91-116.

42. Xu F-T, Li H-M, Yin Q-S, Liang Z-J, Huang M-H, Chi G-Y, et al. Effect of activated autologous platelet-rich plasma on proliferation and osteogenic differentiation of human adipose-derived stem cells in vitro. Am J Transl Res. 2015;7:257-70

43. Gimble JM, Katz AJ, Bunnell BA. Adipose-derived stem cells for regenerative medicine. Circ Res. 2007;100:1249-60.

44. Yan X, Ehnert S, Culmes M, Bachmann A, Seeliger C, Schyschka L, et al. 5-azacytidine improves the osteogenic differentiation potential of aged human adipose-derived mesenchymal stem cells by DNA demethylation. PLoS One. 2014;9:1-10.

45. Ferrer-Lorente R, Bejar MT, Tous M, Vilahur G, Badimon L. Systems biology approach to identify alterations in the stem cell reservoir of subcutaneous adipose tissue in a rat model of diabetes: effects on differentiation potential and function. Diabetologia. 2014;57:246-56.

46. Kim HK, Kim YJ, Kim JT, Kwon CH, Kim YK, Bae YC, et al. Alterations in the proangiogenic functions of adipose tissue-derived stromal cells isolated from diabetic rats. Stem Cells Dev. 2008;17:669-80.

47. Shin L, Peterson DA. Impaired therapeutic capacity of autologous stem cells in a model of type 2 diabetes. Stem Cells Transl Med. 2012;1:125-35.

48. Nambu M, Kishimoto S, Nakamura S, Mizuno H, Yanagibayashi S, Yamamoto $\mathrm{N}$, et al. Accelerated wound healing in healing-impaired $\mathrm{db} / \mathrm{db}$ mice by autologous adipose tissue-derived stromal cells combined with atelocollagen matrix. Ann Plast Surg. 2009;62:317-21.

49. Fiorina P, Pietramaggiori G, Scherer SS, Jurewicz M, Mathews JC, Vergani A, et al. The mobilization and effect of endogenous bone marrow progenitor cells in diabetic wound healing. Cell Transplant. 2010;19:1369-81.

50. Jin P, Zhang X, Wu Y, Li L, Yin Q, Zheng L, et al. Streptozotocin-induced diabetic rat-derived bone marrow mesenchymal stem cells have impaired abilities in proliferation, paracrine, antiapoptosis, and myogenic differentiation. Transplant Proc. 2010;42:2745-52.

51. Khanna S, Biswas S, Shang Y, Collard E, Azad A, Kauh C, et al. Macrophage dysfunction impairs resolution of inflammation in the wounds of diabetic mice. PLoS One. 2010;5:e9539.

52. Lerman OZ, Galiano RD, Armour M, Levine JP, Gurtner GC. Cellular dysfunction in the diabetic fibroblast: impairment in migration, vascular endothelial growth factor production, and response to hypoxia. Am J Pathol. 2003;162:303-12.

53. Tepper OM, Galiano RD, Capla JM, Kalka C, Gagne PJ, Jacobowitz GR, et al. Human endothelial progenitor cells from type II diabetics exhibit impaired proliferation, adhesion, and incorporation into vascular structures. Circulation. 2002;106:2781-6.

54. Terashi H, Izumi K, Deveci M, Rhodes LM, Marcelo CL. High glucose inhibits human epidermal keratinocyte proliferation for cellular studies on diabetes mellitus. Int Wound J. 2005:2:298-304.

55. Acosta L, Hmadcha A, Escacena N, Pérez-Camacho I, De La Cuesta A, RuizSalmeron $\mathrm{R}$, et al. Adipose mesenchymal stromal cells isolated from type 2 diabetic patients display reduced fibrinolytic activity. Diabetes. 2013:62:4266-9.

56. Sze SK, de Kleijn DP, Lai RC, Khia Way Tan E, Zhao H, Yeo KS, et al. Elucidating the secretion proteome of human embryonic stem cell-derived mesenchymal stem cells. Mol Cell Proteomics. 2007;6:1680-9.

57. Park BS, Jang KA, Sung JH, Park JS, Kwon YH, Kim KJ, et al. Adipose-derived stem cells and their secretory factors as a promising therapy for skin aging. Dermatologic Surg. 2008:34:1323-6.

58. Caplan Al, Correa D. The MSC: an injury drugstore. Cell Stem Cell. 2011;9:11-5.

59. Shabbir A, Zisa D, Lin H, Mastri M, Roloff G, Suzuki G, et al. Activation of host tissue trophic factors through JAK-STAT3 signaling: a mechanism of mesenchymal stem cell-mediated cardiac repair. Am J Physiol Heart Circ Physiol. 2010;299:H1428-38.

60. Fatimah SS, Tan GC, Chua K, Fariha MMN, Tan AE, Hayati AR. Stemness and angiogenic gene expression changes of serial-passage human amnion mesenchymal cells. Microvasc Res. 2013;86:21-9.

61. Pricola KL, Kuhn NZ, Haleem-Smith H, Song Y, Tuan RS. Interleukin-6 maintains bone marrow-derived mesenchymal stem cell stemness by an ERK1/2-dependent mechanism. J Cell Biochem. 2009;108:577-88.
62. Martineau I, Lacoste E, Gagnon G. Effects of calcium and thrombin on growth factor release from platelet concentrates: kinetics and regulation of endothelial cell proliferation. Biomaterials. 2004;25:4489-502.

63. Kocaoemer A, Kern S, Klüter H, Bieback K. Human AB serum and thrombinactivated platelet-rich plasma are suitable alternatives to fetal calf serum for the expansion of mesenchymal stem cells from adipose tissue. Stem Cells. 2007;25:1270-8.

64. Zhang Y, He J, Xiao G, Li Q. Effect of platelet-rich plasma on the proliferation and adipogenic differentiation of human adipose-derived stem cells in vitro. Nan Fang Yi Ke Da Xue Xue Bao. 2011;31:525-8.

65. Li H, Liu D, Yu Y, Wu T. Experimental research of the promotion effect of autogeneic PRP on osteogenic differentiation of human adipose-derived stem cells in vitro. Zhongguo Xiu Fu Chong Jian Wai Ke Za Zhi. 2009;23:732-6.

66. Kakudo N, Minakata T, Mitsui T, Kushida S, Notodihardjo FZ, Kusumoto K. Proliferation-promoting effect of platelet-rich plasma on human adiposederived stem cells and human dermal fibroblasts. Plast Reconstr Surg. 2008;122:1352-60

67. Andia I, Rubio-Azpeitia E, Maffulli N. Platelet-rich plasma modulates the secretion of inflammatory/angiogenic proteins by inflamed tenocytes. Clin Orthop Relat Res. 2015;473:1624-34.

68. Loibl M, Lang S, Brockhoff G, Gueorguiev B, Hilber F, Worlicek M, et al. The effect of leukocyte-reduced platelet-rich plasma on the proliferation of autologous adipose-tissue derived mesenchymal stem cells. Clin Hemorheol Microcirc. 2014. doi:10.3233/CH-141920.

69. Kim DY, Ji YH, Kim DW, Dhong ES, Yoon ES. Effects of platelet-rich plasma, adipose-derived stem cells, and stromal vascular fraction on the survival of human transplanted adipose tissue. J Korean Med Sci. 2014;29:S193-200.

70. D'Esposito V, Passaretti F, Perruolo G, Ambrosio MR, Valentino R, Oriente F, et al. Platelet-rich plasma increases growth and motility of adipose tissuederived mesenchymal stem cells and controls adipocyte secretory function. J Cell Biochem. 2015;116:2408-18.

71. Atashi F, Jaconi ME, Pittet-Cuénod B, Modarressi A. Autologous platelet rich plasma: a biological supplement to enhance adipose-derived mesenchymal stem cell expansion. Tissue Eng C Methods. 2015;21:253-62.

72. Van Pham P, Bui KH-T, Ngo DQ, Vu NB, Truong NH, Phan NL, et al. Activated platelet-rich plasma improves adipose-derived stem cell transplantation efficiency in injured articular cartilage. Stem Cell Res Ther. 2013;4:91.

73. Barba-Recreo P, Del Castillo Pardo de Vera JL, Georgiev-Hristov T, Ruiz Bravo-Burguillos E, Abarrategi A, Burgueño M, et al. Adipose-derived stem cells and platelet-rich plasma for preventive treatment of bisphosphonaterelated osteonecrosis of the jaw in a murine model. J Craniomaxillofac Surg. 2015:43:1161-8.

74. Koh YG, Jo SB, Kwon OR, Suh DS, Lee SW, Park SH, et al. Mesenchymal stem cell injections improve symptoms of knee osteoarthritis. J Arthrosc Relat Surg. 2013;29:748-55.

75. Pak J, Chang J-J, Lee JH, Lee SH. Safety reporting on implantation of autologous adipose tissue-derived stem cells with platelet-rich plasma into human articular joints. BMC Musculoskelet Disord. 2013;14:337.

76. Li Q, Zhang A, Tao C, Li X, Jin P. The role of SDF-1-CXCR4/CXCR7 axis in biological behaviors of adipose tissue-derived mesenchymal stem cells in vitro. Biochem Biophys Res Commun. 2013;441:675-80. 